\title{
Determination of phthalates in some milk products by liquid chromatography/tandem mass spectrometry
}

\author{
Seda Dicle KORKMAZ ${ }^{1 a \bowtie}$, Özlem KÜPLÜLÜ̈2b \\ ${ }^{1}$ Giresun University, Espiye Vocational School, Food Processing Department, Giresun; ${ }^{2}$ Ankara University, Faculty of Veterinary \\ Medicine, Department of Food Hygiene and Technology, Ankara, Turkey. \\ aRCID: 0000-0002-4242-300X; ${ }^{\mathrm{b} O R C I D: 0000-0002-1559-2390 . ~}$

${ }^{凶}$ Corresponding author: diclekahraman @ gmail.com
Received date: 25.06.2018- Accepted date: 01.05.2019

\begin{abstract}
This study was aimed to determine the presence and amount of the phthalates in yoghurt and ayran samples consumed in Turkey. For this purpose, 36 yoghurt and 24 ayran samples were used as materials in original packages collected from different markets in Turkey. The presence and the amounts of di-n-butyl phthalate (DBP), di (2-ethylhexyl) phthalate (DEHP), benzyl butyl phthalate (BBP), di-isononyl phthalate (DINP), di-n-octyl phthalate (DNOP) and diisodecyl phthalate (DIDP) were determined by liquid chromatography/tandem mass spectrometry (LC-MS/MS). The results of the analysis howed that DBP, DEHP and BBP were present in the yoghurt samples whereas DINP, DIDP and DNOP were found to be lower than the detectable limit $20 \mu \mathrm{g} / \mathrm{kg}$. The lowest and the highest mounts of DBP, DEHP and BBP in yoghurt samples are 6-229, 24-122, 22-63 $\mu \mathrm{g} / \mathrm{kg}$ respectively. The lowest and highest phthalate amounts in ayran samples are determined to be $38-59 \mu \mathrm{g} / \mathrm{kg}$ for DBP and $26-81 \mu \mathrm{g} / \mathrm{kg}$ for DEHP. According to the results, although DEHP and DBP were the main phthalate esters in all milk products that were analyzed, the phthalate values of the samples were found to be less than the limit values $(\mathrm{P}<0.001)$.
\end{abstract}

Keywords: Dairy products, LC-MS/MS, phthalate, public health.

\section{Bazı süt ürünlerinde likit kromatografi/tandem kütle spektrometresi ile fitalat tayini}

Özet: Bu çalışma Türkiye'de üretim yapan farklı firmalara ait yoğurt ve ayranlardaki fitalat varlığı ve miktarının belirlenmesi amacıyla yapıldı. Bu çerçevede, farklı satış noktalarından orjinal plastik ambalajlarda temin edilen 36 yoğurt ve 24 ayran örneği materyal olarak kullanıldı. Örneklerden di-n-butilfitalat (DBP), di (2-etilhekzil) fitalat (DEHP), benzil butil fitalat (BBP), di-isononil fitalat (DINP), di-n-oktil fitalat (DNOP) ve diizodesil fitalat (DIDP) esterlerinin varlığı ve miktarı likit kromatografi/tandem kütle spektrometresi (LC- MS/MS) ile belirlendi. Analiz sonuçlarına göre, yoğurt ve ayran örneklerinde DBP, DEHP ve BBP esterleri saptanırken DINP, DIDP ve DNOP esterleri saptama sınırının $(20 \mu \mathrm{g} / \mathrm{kg})$ altında bulunmuştur. Yoğurt örneklerine ait en düşük ve en yüksek fitalat değerleri DBP, DEHP ve BBP için sırasıyla 46-229, 24-122, 22-63 $\mu \mathrm{g} / \mathrm{kg}$ olarak saptanmıştır. Ayran örnekleri için en düşük ve en yüksek fitalat değerleri DBP için 38-59 $\mu \mathrm{g} / \mathrm{kg}$, DEHP için 26-81 $\mu \mathrm{g} / \mathrm{kg}$ olarak belirlenmiştir. Buna göre, analize alınan tüm süt ürünlerinde DEHP ve DBP en yüksek oranda saptanan temel fitalat esterleri olmasına ragmen, örneklere ait fitalat değerleri yasal değerlerin oldukça altında bulunmuştur__ $(\mathrm{P}<0.001)$.

Anahtar sözcükler: Fitalat, halk sağlı̆̆1, LC-MS/MS, süt ürünleri

\section{Introduction}

Phthalates are chemical compounds commonly used in the industry. Particularly it is often used as polymer additive in plastics because of providing the flexibility and softness to plastic material. For this reason, they are present in many products such as children toys, gloves, personal care products, printing inks, glues, solvents and including food packaging in particular $(4,6)$. Today, phthalate acidic esters are mostly used as a plasticizer (softener). Di (2-ethylhexyl) Phthalate (DEHP) makes up $50 \%$ of the plasticizer used. DEHP is the most frequently used phthalate. It was started to be produced in United States of America (5). The main usage area is PVC production $(95 \%)$. While it was being used in more than $50 \%$ of PVC products, this amount has decreased in recent years. The use of DEHP has been prohibited across Europe and America especially in food packaging containers, baby rattle and teether and baby toys upon determination of negative effects on human health at the beginning of 2000's $(6,11)$.

DEHP is mixed into the nature through all phases of production, use and disposal. Therefore a major part of the 
substance is present in foods, interior room air and soil. It is biologically accumulated in invertebrate animals, fishes, and plants. However, biomagnifications are not seen in more sophisticated animals and humans due to being metabolized $(14,15)$.

All esters including DEHP in particular, which are added as softener to packaging material, creates an important danger in terms of food safety and public health. The effects of phthalates on human health were revealed with studies conducted. Phthalate esters are known to have endocrine disrupting effect by showing especially estrogenic characteristic. The effects on the organism may vary depending on the age, period, amount of being exposed to phthalates $(14,24)$. In this respect, the most sensitive periods are pregnancy, infancy and puberty periods (16). It is known that among phthalate esters demonstrate adverse effect as follows; DBH, DEHP on germ cell development, BBP on epididymal spermatozoa concentration, DIN and DIDP on liver cells (8). It is explained that the main intake way of phthalates entering into the organism through inhalation, parenteral attempts and skin contact with foods $(7,15)$. Foods are contaminated by plastic material thereby with DEHP for several times during production, packaging and preservation. It has been demonstrated with studies that foods are contaminated by migration of phthalates especially from packaging materials and printing inks. Phthalates may transfer to the food not only from packaging materials, but also from transport, production, storage as well as from soil, water, air and even during cooking in homes $(7,19)$. The phthalate amount in packaged food depends on phthalate concentration in the packaging materials, storage time and temperature, food's fat content and contact surface $(3,6,13)$. The foods with high oil amounts pose an important risk due to phthalates show lipophilic characteristics. Transition occurs much more in oily foods such as milk and dairy products, olive, sunflower oil because of its obvious lipophilic characteristic, albeit the presence of DEHP has been found in many foods $(10,12,20)$. Frequently, isolation in breast milk and from baby foods demonstrates that the interaction with this substance begins in the first years of the life. Determination of presence and amounts of phthalates in foods is essential with respect to public health. Studies conducted in various countries also show that milk and dairy products are major sources for phthalates $(4,15,17,24)$.

Legal regulations on the use of phthalates in many countries of the world have been introduced. The amount of daily intake to be tolerated by European Food Safety Authority (EFSA) was $0.01,0.5,0.05,0.15$ and 0.15 $\mathrm{mg} / \mathrm{kg} /$ day for DBP, BBzP, DEHP, DiNP and DiDP, respectively (9). The legal limit values of $\mathrm{BBP}, \mathrm{DEHP}$, DnBP, DiNP and DiDP should be 30, 1.5, 0.3, 9, $9 \mathrm{mg} / \mathrm{kg}$, respectively which can cause migration when contact with foodstuffs in EU directives; total phthalate levels that can pass from plastics to food are limited to $60 \mathrm{mg} / \mathrm{kg}$ (1). Similar practices and limits with the European Union have been adopted in Turkiye as well (2).

Yoghurt and ayran are sold in plastic packaging in Turkey are dairy products that are consumed commonly by every age segment. The purpose of this study was to determine whether there is a risk of public health or not in terms of phthalate contamination of food samples via analyzing yoghurt and ayran samples which were produced in Turkey.

\section{Materials and Methods}

36 full fat yoghurt and 24 ayran samples, which produced by manufacturing firms and were taken from different markets with original plastic packages used as materials. The samples with different brand and lot numbers were randomly taken from different markets, which were taken to the thermos (cold box) containers and brought to the laboratory immediately. It was kept in the refrigerator $\left(+4^{\circ} \mathrm{C}\right)$ until analysis was made.

Among the samples, the presence and amounts of dibutyl phthalate (DBP), Di (2-ethylhexyl) phthalate (DEHP), benzyl butyl phthalate (BBP), di-'isononyl' phthalate (DINP), Di-n-oktil phthalate (DNOP) and di'isodecyl' phthalate (DIDP) esters were determined by Liquid Chromatography/Tandem Mass spectrometry (LCMS/MS)(Applied Biosystem-3200, USA) (22).

Standard solutions in 20-40-80-120-200 ve 400 $\mu \mathrm{g} / \mathrm{kg}$ were extracted with the standard of DBP (cas no: 84-74-2), DEHP (cas no:117-81-7), BBP (cas no:85-687), DINP (cas no:28553-12-0), DNOP (cas no:117-84-0) and DIDP (cas no:26751-40-0) (Dr.Ehrenstorfer, Augsburg, Germany) esters having stock solutions prepared with hexane for calibration.

The lowest concentration standart was run 20 times to calculate standart deviation. LOD (Limit of detection) value was found as threefold of standart deviation of it. LOQ (Limit of Quantitation) value also came out as 3.3x LOD. For the \% recovery value, mix standart was added to the blank sample to get the $50 \mu \mathrm{g} / \mathrm{kg}$ concentration. 6 separate spiked samples were prepared. According to these values \% recovery and repeatability were calculated. LOQ, Recovery, Relative repeatability standard deviation (RSD), intra-laboratory reproducibility standard deviation (RSD, intra) and R2 values of the method were shown in Table 1.

Samples were homogenized by stirring with a glass stirring rod and weighted $2.00 \mathrm{~g} \pm 0.05$ into a $10 \mathrm{~mL}$ glass test tube. $2 \mathrm{~mL}$ methanol were added and the tube was vortexed $1 \mathrm{~min} .2 \mathrm{~mL}$ hexane and $2 \mathrm{ml}$ tert-butyl methyl ether were added to the solution and centrifuged for 2 minutes at $1500 \mathrm{rpm}$. After the centrifuging, hexane and 
ether phase of the tube was transferred to another tube and hexane and tert-butyl methyl ether addition was repeated. Hexane-ether phase in the mixture was evaporated in a rotary evaporator $\left(70^{\circ} \mathrm{C}\right)$. Residue was dissolved in $2 \mathrm{~mL}$ acetonitrile and was transferred to test tube. $3 \mathrm{~mL}$ hexane was added and mixture was shaken 2 min. Hexane phase in the tube was separated with aid of Pasteur pipette and acetonitrile phase was evaporated in rotary evaporator $\left(70^{\circ} \mathrm{C}\right)$. Residue was dissolved in $0.5 \mathrm{~mL}$ acetonitrile and injected to LC-MS/MS. Analyses were carried out by using C 18-reverse phase (Zorbax Eclipse XDB 50x2,1 mm $1.8 \mu$ ) column with an 80:20 water - methanol mobile phase as starting conditions and flow of $0.3 \mathrm{~mL} / \mathrm{min}$. Injection volume was $5 \mu \mathrm{l}$ (22). MS parameters used for the analysis are given in Table 2.

Statistical analysis: One sample t-test was used to compare the DEHP and DBP values with the legal limit values.

Table 1. LOQ, Recovery \%, Relative repeatability standard deviation (RSD), intra-laboratory reproducibility standard deviation (RSD, intraday) and $\mathrm{R}^{2}$ values of the method.

Tablo 1. Metoda ait LOQ, \% Geri Kazanım, Tekrarlanabilirlik (RSD, RSD, intra) ve $\mathrm{R}^{2}$ değerleri.

\begin{tabular}{lccccc}
\hline Phthalate Esters & LOQ $(\boldsymbol{\mu g} / \mathbf{k g})$ & Recovery $\%$ & RSD $(\boldsymbol{\%})$ & RSD, intraday $(\boldsymbol{\%})$ & Calibration R $^{\mathbf{2}}$ value \\
\hline DBP & 30 & 87.2 & 12 & 16 & 0.9961 \\
DEHP & 20 & 83.9 & 14 & 18 & 0.9907 \\
BBP & 20 & 90.9 & 12 & 18 & 0.9951 \\
DINP & 20 & 96.1 & 13 & 18 & 0.9895 \\
DNOP & 20 & 92.8 & 12 & 16 & 0.9918 \\
DIDP & 20 & 85.5 & 14 & 19 & 0.9972 \\
\hline
\end{tabular}

Table 2. Instrument parameters for the analysis.

Tablo 2. Analiz için kullanılan sistem parametreleri.

\begin{tabular}{ll}
\hline Parameters & Description \\
\hline Column & Agilent Zorbax SB-C18 column $2.1 \mathrm{~mm} \times 50 \mathrm{~mm} \times 1.8 \mu \mathrm{m}$ \\
Column temp. & $35 \circ \mathrm{C}$ \\
Injection volume & $5 \mu 1$ \\
Mobile phase A & $0.1 \%$ Formic acid in water \\
Mobile phase B & Methanol \\
Flow rate & $0.3 \mathrm{ml} / \mathrm{min}$ \\
Gradient & 0 min- $20 \% \mathrm{~B}$ \\
& $0.5 \mathrm{~min}-20 \% \mathrm{~B}$ \\
& $3 \mathrm{~min}-95 \% \mathrm{~B}$ \\
& $6 \mathrm{~min}-95 \% \mathrm{~B}$ \\
& $6.1 \mathrm{~min}-20 \% \mathrm{~B}$ \\
& $8.5 \mathrm{~min}-20 \% \mathrm{~B}$ \\
Run time & $9 \mathrm{~min}$ \\
Ionisation mode & Positive electrospray ionisation mode with jet stream technology \\
Drying gas temp & $325 \circ \mathrm{C}$ \\
Drying gas flow & $11 \mathrm{~L} / \mathrm{min}$ \\
Nebuliser & $35 \mathrm{psi}$ \\
\hline
\end{tabular}

\section{Results}

Ionisation parameters for each compound were optimized to achieve better sensitivity and robustness. A total of 60 samples including 36 yoghurt, 24 ayran samples were analyzed in the study. Extracted Ion Chromatogram (EIC) of standard mixture of 6 phthalate compounds with a concentration of $40 \mu \mathrm{g} / \mathrm{kg}$ (Calibration Level 2) can be seen in Figure 1. Each compound has 2 MRM transitions. Transitions used for the analysis were given in Table 3.
According to results DBP, DEHP, and BBP were present in the samples whereas DINP, DIDP and DNOP esters were found to be lower than the detection limit 20 $\mu \mathrm{g} / \mathrm{kg}$. The highest values of DBP, DEHP, and BBP in yoghurt samples were found to be 229,122 and $63 \mu \mathrm{g} / \mathrm{kg}$ respectively, the lowest values were 46, 24 ve $22 \mu \mathrm{g} / \mathrm{kg}$ (Table 4). The highest values of DBP and DEHP in ayran samples were found to be 59 and $81 \mu \mathrm{g} / \mathrm{kg}$, the lowest values were 38 ve $26 \mu \mathrm{g} / \mathrm{kg}$ (Table 5). All the values found have been determined under the legal limit values $(\mathrm{P}<0.001)$ 


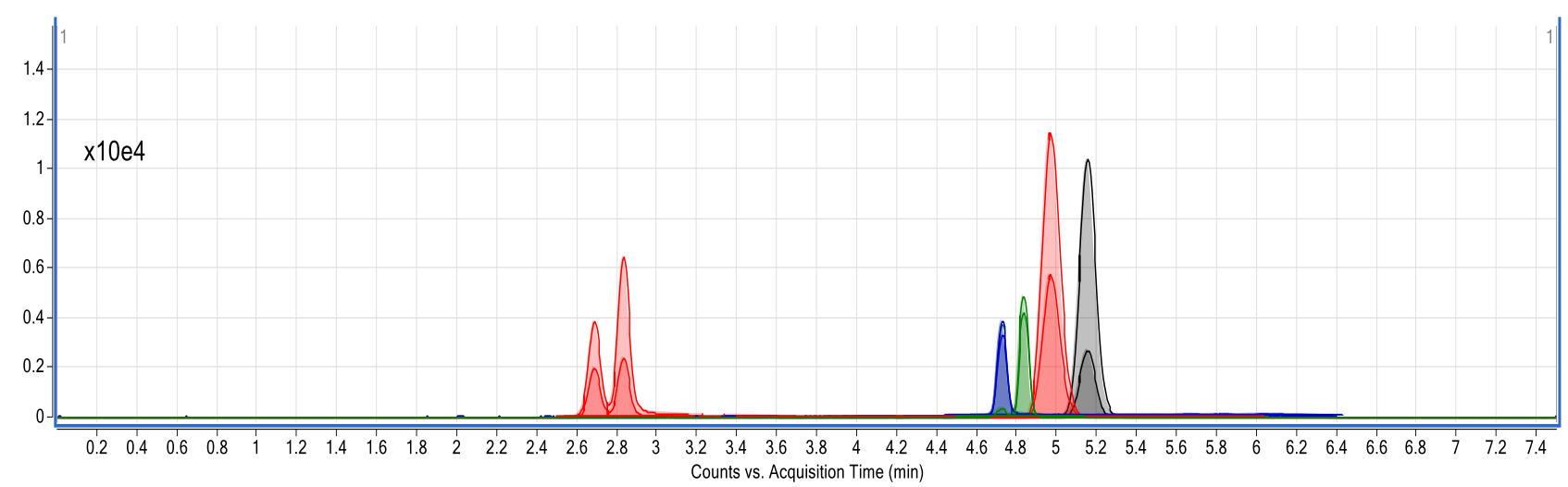

Figure 1. Extracted Ion Chromatogram, EIC, of standard mixture of 6 phthalate compounds with a concentration of $40 \mu \mathrm{g} / \mathrm{kg}$ (Calibration Level 2).

Şekil 1. Fitalat esterlerinin $40 \mu \mathrm{g} / \mathrm{kg}$ derişimde ekstrakte edilmiş iyon kromatogramları.

Table 3. MRM transitions and Retention Time values.

Tablo 3. MRM geçişleri ve alıkonma değerleri $(\mu \mathrm{g} / \mathrm{kg})$.

\begin{tabular}{lcccc}
\hline Phthalate esters & Precursor ion & Product ion1 & Product ion2 & Retention time (min.) \\
\hline DBP & 279 & 205 & 149 & 2.67 \\
DEHP & 391 & 167 & 149 & 4.72 \\
BBP & 313 & 205 & 149 & 2.85 \\
DINP & 419 & 275 & 149 & 4.96 \\
DIDP & 447 & 289 & 149 & 5.20 \\
DNOP & 391 & 121 & 261 & 4.83 \\
\hline
\end{tabular}

Table 4. Phthalate values $(\mu \mathrm{g} / \mathrm{kg})$ of yoghurt samples.

Tablo 4. Yoğurt örneklerine ait fitalat değerleri $(\mu \mathrm{g} / \mathrm{kg})$.

\begin{tabular}{|c|c|c|c|c|c|c|c|c|c|c|c|c|c|}
\hline No & DBP & DEHP & BBP & DIDP & DINP & DNOP & No & DBP & DEHP & BBP & DIDP & DINP & DNOP \\
\hline 1 & 89 & 35 & ND & ND & ND & ND & 19 & 113 & 76 & ND & ND & ND & ND \\
\hline 2 & 136 & 53 & ND & ND & ND & ND & 20 & 166 & 92 & ND & ND & ND & ND \\
\hline 3 & 77 & ND & ND & ND & ND & ND & 21 & 105 & 66 & ND & ND & ND & ND \\
\hline 4 & 54 & $24 * *$ & ND & ND & ND & ND & 22 & 213 & $122 *$ & 46 & ND & ND & ND \\
\hline 5 & 172 & 90 & 33 & ND & ND & ND & 23 & $229 *$ & 109 & 33 & ND & ND & ND \\
\hline 6 & 110 & 49 & $22 * *$ & ND & ND & ND & 24 & $46^{* *}$ & ND & ND & ND & ND & ND \\
\hline 7 & ND & ND & ND & ND & ND & ND & 25 & 80 & 44 & ND & ND & ND & ND \\
\hline 8 & 159 & 75 & ND & ND & ND & ND & 26 & 152 & 88 & ND & ND & ND & ND \\
\hline 9 & 99 & 44 & ND & ND & ND & ND & 27 & 110 & 95 & ND & ND & ND & ND \\
\hline 10 & 78 & 37 & ND & ND & ND & ND & 28 & 116 & 98 & ND & ND & ND & ND \\
\hline 11 & 101 & 49 & ND & ND & ND & ND & 29 & 92 & ND & ND & ND & ND & ND \\
\hline 12 & 188 & 96 & 40 & ND & ND & ND & 30 & 62 & 38 & ND & ND & ND & ND \\
\hline 13 & 170 & 112 & $63 *$ & ND & ND & ND & 31 & ND & ND & ND & ND & ND & ND \\
\hline 14 & 80 & ND & ND & ND & ND & ND & 32 & 105 & 52 & ND & ND & ND & ND \\
\hline 15 & 181 & 86 & 24 & ND & ND & ND & 33 & 100 & ND & ND & ND & ND & ND \\
\hline 16 & 91 & 46 & ND & ND & ND & ND & 34 & 85 & 35 & ND & ND & ND & ND \\
\hline 17 & 81 & 40 & ND & ND & ND & ND & 35 & 142 & 68 & ND & ND & ND & ND \\
\hline 18 & 196 & 101 & ND & ND & ND & ND & 36 & 102 & 60 & ND & ND & ND & ND \\
\hline
\end{tabular}

*: The highest phthalate ester value, **: The lowest phthalate ester value. Detectable Limit: $(20 \mu \mathrm{g} / \mathrm{kg})$, ND: Not determined 
Table 5. Phthalate values $(\mu \mathrm{g} / \mathrm{kg})$ of ayran samples.

Tablo 5. Ayran örneklerine ait fitalat değerleri $(\mu \mathrm{g} / \mathrm{kg})$.

\begin{tabular}{|c|c|c|c|c|c|c|c|c|c|c|c|c|c|}
\hline No & DBP & DEHP & BBP & DIDP & DINP & DNOP & No & DBP & DEHP & BBP & DIDP & DINP & DNOP \\
\hline 1 & ND & 30 & ND & ND & ND & ND & 13 & 50 & 71 & ND & ND & ND & ND \\
\hline 2 & $38 * *$ & 51 & ND & ND & ND & ND & 14 & ND & ND & ND & ND & ND & ND \\
\hline 3 & ND & ND & ND & ND & ND & ND & 15 & 48 & 67 & ND & ND & ND & ND \\
\hline 4 & ND & ND & ND & ND & ND & ND & 16 & ND & 45 & ND & ND & ND & ND \\
\hline 5 & 45 & 60 & ND & ND & ND & ND & 17 & ND & 34 & ND & ND & ND & ND \\
\hline 6 & ND & $26^{* *}$ & ND & ND & ND & ND & 18 & ND & 54 & ND & ND & ND & ND \\
\hline 7 & $59 *$ & ND & ND & ND & ND & ND & 19 & 46 & 63 & ND & ND & ND & ND \\
\hline 8 & 46 & 67 & ND & ND & ND & ND & 20 & 55 & 70 & ND & ND & ND & ND \\
\hline 9 & 57 & $81^{*}$ & ND & ND & ND & ND & 21 & 48 & 75 & ND & ND & ND & ND \\
\hline 10 & 39 & 50 & ND & ND & ND & ND & 22 & ND & ND & ND & ND & ND & ND \\
\hline 11 & ND & ND & ND & ND & ND & ND & 23 & 50 & 68 & ND & ND & ND & ND \\
\hline 12 & 41 & 53 & ND & ND & ND & ND & 24 & 56 & ND & ND & ND & ND & ND \\
\hline
\end{tabular}

*: The highest phthalate ester value, ${ }^{* *}$ : The lowest phthalate ester value. Detectable Limit: $(20 \mu \mathrm{g} / \mathrm{kg}), \mathrm{ND}$ : Not determined

\section{Discussion and Conclusion}

Tandem MS technique with being capable of more selective and more sensitive with respect to other single MS techniques let us analyse more complex matrices even without a significant sensitivity lost. The presence and quantity of 6 separate phthalate esters in yoghurt and ayran were researched in the study. According to analysis results DBP, DEHP, and BBP were present in the samples whereas DINP, DIDP and DNOP esters were found to be lower than the detection limit $20 \mu \mathrm{g} / \mathrm{kg}$. While the highest values of DBP, DEHP, and BBP in yoghurt samples were found to be 229,122 ve $63 \mu \mathrm{g} / \mathrm{kg}$ respectively, the lowest values were 46,24 , and $22 \mu \mathrm{g} / \mathrm{kg}$. While the highest values of DBP and DEHP in ayran samples were found to be 59 and $81 \mu \mathrm{g} / \mathrm{kg}$ respectively, the lowest values were 38 and $26 \mu \mathrm{g} / \mathrm{kg}$. Accordingly, DEHP and DBP were found to be main phthalate esters determined at the highest rate in all dairy products taken to the analysis.

Some studies were encountered in foods such as raw milk, pasteurized milk, butter, cheese, baby food related to searching phthalates in dairy products, but it was seen that no study was conducted related to ayran, and only one study was available related to yoghurt (10). It is stated that DEHP level in fruity yoghurt is $15-37 \mu \mathrm{g} / \mathrm{kg}$, and DBP, BBP, DINP and DIDP are below the detectable limit in the research done by Sorensen on milk and dairy products. In this study, the following values were found in yoghurt samples as; DEHP 24-122 $\mu \mathrm{g} / \mathrm{kg}$, DBP $46-229 \mu \mathrm{g} / \mathrm{kg}$, BBP $22-63 \mu \mathrm{g} / \mathrm{kg}$, In this study, the results are higher than the values found by Sorensen, 2006 (22). Similarly to our study, Sireli et al. (2017) determined 6 phthalate esters (DEHP, BBP, DBP, DNOP, DEP and DMP) in yoghurt and fruits yoghurt samples by using GC-MS. According to this study, DEHP concentration values of the samples were similar to our results. However the concentration values of DBP and BBP were lower than our results (21). Zhoukun et al. (2011) in this study which they examined 9 types of phthalate esters in dairy products; in all the samples the main phthalate ester was DBP with a value of $100 \mathrm{ng} / \mathrm{kg}$. The other results are similar to our study (24). It is thought that this difference might arise from air, water, storage conditions in addition to packaging material and printing ink used. Furthermore, fat content also affects the migrations of phthalates having lipophilic characteristic (10). The phthalate amounts in packaged foods depend on phthalate concentration in packaging material, storage time and temperature, fat content of the food and contact surface. The levels of phthalate esters which exist in ayran samples were found lower than yoghurt samples as expected because of water ratio of samples (20).

It was seen that phthalate esters were at different levels in other studies $(13,17)$ conducted on milk and dairy products. It is thought that this situation results from production, transport and storage conditions, including packaging material and food's fat amount in particular. In addition, the existence of different legal regulations concerning the packaging material in countries is among the causes of differences in studies.

In conclusion, considering the phthalate sources that milk products may be exposed to, it has been concluded that phthalate contamination that can reach on uncontrolled high level could pose a potential risk. DEHP, which is the most commonly used phthalate ester during production, processing and protection of foods, is considered among the group of "endocrine disrupting chemical substance" because of having estrogen agonist, testosterone antagonist. It is known that children 
especially are more sensitive to this effect $(8,18)$. Additionally carcinogenic, teratogenic and mutagenic effect created by phthalates on animals is also a crucial threat for human health $(16,18,23)$. Therefore, bringing the contamination by phthalates under control the contamination by from farm to table, and the use of alternative materials not containing phthalates in food's packaging are of great importance.

\section{References}

1. Anonymous (2007): Commission Directive 2007/19/EC of 30 March 2007 amending Directive 2002/72/EC relating to plastic materials and articles intended to come into contact with food and Council Directive 85/572/EEC laying down the list of simulants to be used for testing migration of constituents of plastic materials and articles intended to come into contact with foodstuffs.

2. Anonymous (2013): Türk Glda Kodeksi Gıda İle Temas Eden Plastik Madde ve Malzemelerin Bileşenlerinin Migrasyon Testinde Kullanilan Gida Benzerleri Listesi Tebliği. Tebliğ No: 2013/35.

3. Balafas D, Shaw KJ, Whitfield FB (1999): Phthalate and adipate esters in Australian packaging materials. Food Chem, 65, 279-287.

4. Bradley EL, Burden RA, Leon I, et al. (2013): Determination of phthalate diesters in foods. Food Addit Contam, 30, 722-734.

5. Cao X (2008): Determination of phthalates and adipate in bottled water by headspace solid-phase microextraction and gas chromatography/mass spectrometry. J Chromatogr A, 1178, 231-238.

6. Chen M, Chen J, Tang C, et al. (2008): The internal exposure of Taiwanese to phthalate- An evidence of intensive use of plastic materials. Environ Int, 34, 79-85.

7. Chou K, Wright RO (2006): Phthalates in Food and Medical Devices. J Med Toxicol, 2, 126-135.

8. Durmaz E, Özmert EN (2010): Fitalatlar ve çocuk sağlı̆̆l. Çocuk Sağ Hast Derg, 53, 305-317.

9. EFSA European Food Safety Authority (2005): Statement on the possibility of allocating a group-TDI for certain phthalates.

10. Farhoodi M, Djomeh ZE, Ehsani, MR (2008): Effect of environmental conditions on the migration of di (2ethylhexyl) Phthalate from pet bottles into yogurt drinks: Influence of time, temperature, and food stimulant. Arabian J Sci Eng, 33, 279-287.
11. Fasano E, Bono-Blay F, Cirillo T, et al. (2012): Migration of phthalates, alkylphenols, bisphenol $A$ and $d i$ (2ethylhexyl) adipate from food packaging. Food Control, 27,132-138.

12. Fierens T, Van Holderbeke M, Willems H, et al. (2012): Phthalates in Belgian cow's milk and the role of feed and other contamination pathways at farm level. Food Chem Toxicol, 50, 2945-2953.

13. Fierens T, Van Holderbeke M, Willems H, et al. (2013): Transfer of eight phthalates through the milk chain- A case study. Environ Int, 52, 1-7.

14. Frederiksen H, Skakkebaek NE, Andersson A (2007): Metabolizm of phthalates in humans. Mol Nutr Food Res, 51, 899-911.

15. Jarosova A (2006): Phthalic Acid Esters ( PAEs) in the Food Chain. Czech J Food Sci, 24, 223-231.

16. Kamrin MA (2009): Phthalate risks, Phthalate regulation and Public health: A rewiew. J Toxicol Environ Health Part B, 12, 157-174.

17. Kim M, Yun SJ, Chung, GS (2009): Determination of phthalates in raw bovine milk by gas chromatography/timeof-flight mass spectrometry (GC/TOF-MS) and dietary intakes. Food Addit Contam, 26, 134-138.

18. Latini G, Verrotti A, De Felice C (2004): Di-2-ethylhexyl phthalate and endocrine disruption: a rewiew. Curr Drug Targets: Immune, Endocr Metab Disord, 4, 37-40.

19. Lin J, Chen W, Zhu H, et al. (2015): Determination of free and total phthalates in commercial whole milk products in different packaging materials by gas chromatographymass spectrometry. J Dairy Sci, 98, 8278-8284.

20. Sanino A (2009): Survey of phthalate levels in Italian oily foods contained in glass jars with PVC gaskets. Food Addit Contam Part B, 2, 166-170.

21. Sireli UT, Filazi A, Yurdakök-Dikmen B, et al. (2017): Determination of phthalate residues in different types of yogurt by gas chromatography-mass spectrometry and estimation of yogurt-related intake of phthalates. Food Anal Methods, 10, 3052-3062.

22. Sorensen KL (2006): Determination of phthalates in milk and milk products by liquid chromatography/tandem mass spectrometry. Rapid Commun Mass Spectrom, 20, 11351143.

23. Wittassek M, Angerer J (2008): Phthalates: metabolism and exposure. Int J Androl, 31, 131-138.

24. Zhuokun L, Liguong X, Chifang P, et al. (2011): Simultaneous determination of nine types of phthalate residues in commercial milk products using HPLC-ESI-MSMS. J Chromatogr Sci, 49, 337-343. 